\title{
Paris Barış Konferansı Yolunda Azerbaycan Cumhuriyeti
}

\section{Dursun Ali Akbulut*}

\section{Özet}

Azerbaycan, Bolşevik ihtilalinden sonra hükümetini kurdu ve 28 Mayıs'ta cumhuriyetini ilan etti. Aynı yolu izleyen Kafkas berisindeki komşularıyla ilişkilerini geliştirmeye çalıştı ve doğal başkenti Bakü'ye Kafkas İslam Ordusu sayesinde, 15 Eylül'de kavuştu. Bağımsızlığını uluslararası seviyede temsil ettirmek, çağdaş devletler camiasında yerini alabilmek için Gürcistan ve Ermenistan Cumhuriyetleriyle birlikte hareket etti. Osmanlı Devleti sadece Azerbaycan için değil, diğer iki cumhuriyetle de vazgeçilemez yapıda ve konumda idi. Önce İstanbul'a geldiler, sonra Paris'in yolunu tuttular. Orada günlerce hatta aylarca kaldılar. Özellikle Azerbaycan ve Gürcistan murahhasları kader birliği etmişçesine Yüksek Konseyin huzurunda beklentilerini ve temennilerini dile getirdiler. Bağımsızlıklarını tanıttırdılar, Bolşeviklere karşı yardım sözü aldılar. Asgari şartlar altında da olsa elde ettikleriyle umutlandılar. Azerbaycan ve onun yanında Gürcistan'la ilgili gelişmeler İstanbul'u da memnun etti. Ne var ki batı dünyası tercihini Büyük Rusya'dan yana kullandı.

Anahtar Kelimeler: Azerbaycan, Bakü, Bolşevik, İstanbul, Osmanlı, Paris Barış Konferansı.

\section{Republic of Azerbaijan on the Way to the Paris Peace Conference}

\section{Abstract}

After the Bolshevik Revolution, Azerbaijan eztablished its goverment and on 28th May declared its republic. Azerbaijan tried to develop relations with its Caucasus side neigbours who were following the same path. Azerbaijan gained its natural capital city Baku, on September 15th, tanks to İslamic Army of the Caucasus. It has acted together with the Republic of Georgia and Republic of Armenia to allow its independence to be accepted at the internatial level and to take its place among to contemporary states. The Ottoman Empire was indispensable not only for Azerbaijan but also for the other two contries. They first came to Istanbul then took to road to the paris.

\footnotetext{
* Prof. Dr., Ondokuz Mayıs Üniversitesi, Eğitim Fakültesi, Ortaöğretim S.E.A. Bölümü, dakbulut@omu.edu.tr. (ORCID ID: 0000-0003-1562-1099).

(Makale Gönderim Tarihi: 21.08.2017, Makale Kabul Tarihi: 20.09.2017)
}

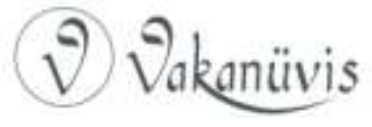


They stayed there for days even months. In particular the delegates of Azerbaijan and Gergia expressed their hopes and wishes in the presence of the High Council. They promoted their independence, and received a promise of helping against Bolsheviks. They were hoped for what they gained even under minimal conditions. The developments regarding Azerbaijan and its beside Georgia plased Istanbul. However, the vestern world used the perference of Great Russia.

Keywords: Azerbaijan, Baku, Bolshevik, Istanbul, Ottamans, Paris Peace Conference.

19 Yüzyılın başlarında Çarlık Rusyası'nın işgaline uğrayan Azerbaycan bir yüzyıl kadar sonra 20. Yüzyılın ilk çeyreğinde 28 Mayıs 1918 'de Birinci Cumhuriyeti'ni Tiflis'te ilan etti, akabinde yeni cumhuriyetin başkenti Gence oldu. Bakü'nün 15 Eylül 1918'de Kafkas İslam Ordusu tarafından kurtarılmasından sonra hükümet daireleri buraya taşınmaya başladı. Hemen hemen aynı tarihlerde itilaf devletleriyle ittifak devletleri arasında mütarekeler yapılarak Birinci Dünya Savaşı'na son verildi. İki aydan fazla bir süre geçtikten sonra 18 Ocak 1919'da Paris Barış Konferansı toplandı. Bu konferansa sadece galip statüsünde 32 devlet davet edildi, mağlup devletler, haklarında düzenlenen anlaşmaları imzalamak üzere konferansa çağırıldılar. Barış Konferansı'nın en önemli gündemi bu olmakla birlikte, bir Milletler Cemiyeti Yasası gerçekleştirilmek isteniyor, bu çerçevede her türlü azınlık temsilcileri Paris'in yolunu tutuyordu. Paris Barış Konferansı sürecine Kafkas berisi cumhuriyetleri de dahil olmak istediler. Azerbaycan Cumhuriyeti, Aralık 1918'de konferansa katılmak üzere harekete geçti. Önce Paris'e gönderilecek delegasyonun terkibi ve statüsünün belirlenmesi için faaliyette bulundular. Parlamento reisi Ali Merdan Topçubaşıyef'in ${ }^{1}$ başkanlığında bir heyet oluşturularak 4 Ocak

\footnotetext{
${ }^{1}$ İstanbul basınında Azerbaycan ile ilgili haberler yer almaktaydı. Zaman gazetesinin 5 Ocak 1919 tarih ve Azerbaycan Kabinesinde Tebeddülat-Ali Merdan Bey Başvekil unvanlı haberinde, Azerbaycan kabinesinin istifa ettiği, Ali Merdan Topçubaşıyef'in yeni hükümeti kurmaya memur edildiği, kendisinin İstanbul'da bulunması nedeniyle bundan haberdar bulunmadığı, üstelik ikinci yasama yılına başlayan Azerbaycan Milli Meclisinin Ali Merdan Beyi başkanlığa seçtiği, bununla birlikte seçim keyfiyetinin kendisine ulaştırılamadığı belirtilmekte, aynı nüshanın Kafkasya Hakkında Broşürler başlığı altında "Azerbaycan'ın Istanbul sefiri Ali Merdan Bey tarafından Kafkasya ve
}

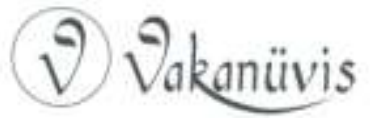


1919'da Bakü'den hareketle Tiflis ve Batum'da görüşmelerde bulundular. 20 Ocak 1919 'da İstanbul'a gelen Azerbaycan heyeti itilaf askerleri sebebiyle burada zorluklarla karşılaştı. Hüseyinzade Ali Bey, Bekirağa Bölüğünde bir süre hapsedildikten sonra kurtuldu, Ahmet Ağaoğlu tutuklanarak Malta'ya sürüldü ${ }^{2}$. Heyettekiler uzun süre vize beklediler. Nihayet üç ay kadar sonra 22 Nisan 1919'da Paris'e hareket edebildiler ${ }^{3}$. Kafkas Azerbaycanı Cumhuriyeti'nin Paris Sulh Konferansı'na Memorandumu hazırladılar, İngilizce ve Fransızca olarak yayınladılar. Diğer heyetlerle görüşmelerde bulundular. 23 Mayıs 1919'da İngiliz heyetinden bir yetkili ile görüştüler, cumhuriyetin birinci yıldönümü münasebetiyle 28 Mayıs 1919'da ABD Başkanı Wilson, heyeti kabul etti. Ali Merdan Topçubaşıyef, Azerbaycan'ın konferanstan beklentilerini ve taleplerini Wilson'a iletti. 31 Mayıs'ta Topçubaşıyef, konferans başkanına bir mektup yazarak Azerbaycan'ın bağımsızığının tanınmasını istedi. Kasım 1919'da İngilizler Azerbaycan ve Gürcistan'ın tanınmasını önerdiler. Bunun üzerine Azerbaycan Heyeti, Milletler Cemiyeti'ne giriş başvurusunda bulundu. 13 Ocak

Azerbaycan hakkında bir broşür tertip ve neşredileceğini yazmıştık. Fansızca ve Türkçe yazılmış olan bu broşürlerden Fransızcası çıkmış ve itilafçılara tevzi olunmuştur. Türkçesi basılmaktadır." deniliyordu. 20 Ocak 1919 tarihli ve Azerbaycan ve Gürcistan Sulh Murahhasları başlıklı yazısında Azerbaycan ve Gürcistan heyetlerinin hazırlanıp yola çıkarıldıkları, İstanbul'a gelmelerinin beklendiği, Azerbaycan'ın İstanbul'daki sefiri Ali Merdan Topçubaşı'nın hükümet tarafından heyet başkanlığına tayin edildiği belirtiliyordu. Anadolu'da Yeni Gün gazetesi Azerbaycan Heyet-i Murahhasası başlıklı haberinde: "Azerbaycan Hükümeti namına Paris Barış Konferansında ispat-ı vücut etmek üzere gönderilen heyet-i murahhasa evvelki gün şehrimize muvasalat etmiştir. Heyet-i Riyaseti Azerbaycan Hükümetinin Babıali nezdine fevkalade elçi sıfatıyla memur ettiği Meclis-i Milli Reisi Ali Merdan Bey Topçubaşıyef tayin edilmiştir. Heyet-i Murahhasa beynelmilel meclislere iştirak etmek, siyasi iktisadi, mali taahhütnameler aktine selahiyettar bulunmak gibi vasi selahiyetlere maliktir... Heyet, Kafkasya'da Ingiliz kuvası kumandanı General Thomson'ın mektuplarını hamildir." deniliyor ve heyetin on beş kişiden ibaret olduğunu kaydediyordu (Yeni Gün, 23 Kânunusani 1335/23 Ocak 1919).

${ }^{2}$ Azerbaycan, 11 Nisan 1919. Haber, Ahmet Bey Agayef'in istanbul'da Tevkifi başlığı altında verilmiştir. İstiklal gazetesi de 15 Mart 1919 tarihli nüshasında, Ağaoğlu Ahmet Beyin evvelki gün (13 Mart) hanesinde arandığını fakat bulunamadığını haber vermekteydi.

${ }^{3}$ Azerbaycan Cumhuriyetinin Ansiklopedisi, c. II, Bakü 2005, s. 282 vd. Heyettekiler: Başkan Yardımcısı Memmed Hasan Hacinski, Parlamento üyeleri: Ahmet Ağaoğlu ve Ekberağa Şeyhülislamov, Maslahatçılar: Mir Yakup Mehdiyev, Ceyhun Hacinski, Mehemmed Meherremov.

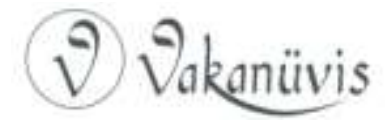


1920'de Paris'teki Yüksek Konsey, İngiliz Dışişleri Bakanı Lord Curzon'un Azerbaycan'ın bağımsızlığı teklifini de facto olarak tanıdı. Aynı zamanda, müttefikler ve Milletler Cemiyeti üyeleri de Azerbaycan'ın yanı sıra Gürcistan'ın da bağımsızlıklarını de facto düzeyde tanıdılar".

$\mathrm{Bu}$ özet bilgilere istinaden gerek Azerbaycan, gerek Osmanlı basınında olayla ilgili anlatımları mümkün olduğu kadarıyla bir araya getirmek suretiyle konuya bir başka çerçeveden bakmak gereklidir. Nitekim 3 Ocak 1919 tarihli Azerbaycan gazetesindeki değerlendirme yazısında, hükümet ve parlamentonun sulh konferansında Azerbaycan'ın bağımsızlığını savunmak için bir heyeti yola çıkarmak üzere olduğu, heyetin üzerine düşen sorumluluğun zor ve ağır derecede bulunduğu ifade edildikten sonra şu görüşlere yer veriliyordu: "Heyet-i Murahhasa öz mukaddes vazifesini kâfi bir surette ifa edebilip, memleketin ve milletin hukuk ve şerefini müdafaa etmeğe muvaffak olacak diye ümit beslemek üzereyiz. ${ }^{\prime \prime}$

"Sulh Kongresine Giden Heyet-i Murahhasanın Azimeti" başlığı altında H.E. imzasıyla yer alan diğer bir yazıda deniliyordu ki:

"Azerbaycan Parlamenti tarafindan Avrupa'ya ve Azerbaycan tarafindan umumi sulh kongresine gönderilen heyet-i murahhasa Çarşamba günü saat 7'de demiryolu tarikiyle azimet etti. Devlet müfettişi Müsavat pişrevi Mehmed Han Hacinski, Parlman mebusu ve meşhur cemaat hadimi Ahmed Bey Ağayev, meşhur cemaat hadimi Ali Merdan Bey Topşubaşıyef, Parlman uzvu ve Sosyalist Himmet Fırkası Reisi Ekber Ağa Ağayef, gazetemizin müdürü ve başmuharriri Ceyhun Bey Hacıbeyli, Maharremov (Sosyalist) ve Mir Yakup Mirmehdiyef (ittihat) cenaplarından ibaretti.

\footnotetext{
${ }^{4}$ Azerbaycan, 30 Mayıs 1918 de radyogramla bağımsız devlet olduğunu ilan etmiş, Türkiye dahil 18 ülke tarafından tanınmıştı. Ancak bu ülkelerin başkentlerinde elçilik açmak ya da sefir bulundurmak imkânını bulamadığından Dışişleri Bakanı Hacinski, mahrem bir telgrafla Osmanlı Hariciye Nazırı Ahmet Nesimi Beyden ricada bulunmuştur ki Avrupa devletlerindeki Osmanlı sefirlikleri Azerbaycan'ın temsiliyetini üstlensinler. Bunu müteakiben devlet merkezi Tiflis'ten Gence'ye taşındı. Tiflis, İlk Cumhuriyetin geçici başkenti olmuş, yeni Azerbaycan Cumhuriyetine, 27 Mayıs 1918 den 17 Haziran 1918 e kadar yirmi gün başkentlik yapmıştır (Azerbaycan Halk Cumhuriyet Ansiklopedisi, c. I, Bakı 2005, s. 28 vd.)

${ }^{5}$ Azerbaycan, 3 Kânunusani/ 3 Ocak 1919.
}

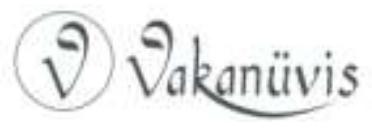


Heyet-i murahhasayı teşyi için başta Fethali Han Hoyski olmak üzere umum uzuvlar, Meclis-i Mebusan azasının bir çoğu, hususen firaksiya ve fırka reisleri ve bir çok sair karakol destesi konulmuştu. Heyete, yola düşmeden evvel Müsavat Fırkası Reisi Resulzade Mehmed Emin Bey cenapları muhtasar bir nutuk irat ederek Avrupa'ya giden meşhur, çalışkan reislerimize vazifeleri hakkında bir söz söylemeyi artık hesap edip de ancak vekillerimizin millet huzuruna istiklal temini gibi mübarek beşaretle ak yüz, açık alınla kayıtacaklarına emin olduğunu bildiriyor.

Bade, Sosyalist Fırkası namına Ahmed Cevdet cenapları bir nutuk diyerek Azerbaycan demokrasiyası tarafından bütün Avrupa'ya ve cihan demokrasiyayına selam yetermelerini ve dünya fukara-yı kâsibesinden bize amal ve arzumuzun husulü beşareti getirmelerini arzu ediyor.

Heyet-i murahhasa tarafından Ağaoğlu Ahmet Bey Hazretleri cevabi nutuk irat ederek bu gün vatanda gördükleri haller, hareketlerin heyet-i murahhasa uhdesine düşen ağır vazifenin hüsn-ü ifasına ve istiklale layık olan bir milletin istiklaliyetini temin edebileceklerine olan iman ve itikatlarını bir daha kuvvetlendirdiğini ve binaenaleyh heyet, var kuvvesiyle milletin arzusuna nail olacağına çalışacağını, bu yolda da muvaffak olacaklarına inandığını beyan ediyor. Sürekli hurra sedası içinde katar yola düştü. "'6

23 Ocak 1919 tarihli Ingiltere ve Azerbaycan başlıklı diğer bir haber, Fethali Han Hoyski'nin Balkan ve Kafkasya'da umum İngiltere birlikleri başkomutanı Sir George Milne ile görüştüğünü, burada Milne'in, İngiliz hükümetinin Azerbaycan Cumhuriyeti'ni tanıdığını ve kabul ettiğini, müttefik komutanlı̆̆ının Azerbaycan'a yardım edeceğini söylediği bildirilmiştir. Milne ayrıca şunu da beyan etmiştir ki müttefik başkomutanlığı Güney Kafkasya Hükümetlerinin iç işlerine karışmayacak, bu devletlerdeki düzenin sağlanmasına yardımcı olacaktır ${ }^{7}$.

Resulzade Mehmet Emin Bey, Siyasi Vaziyetimiz başlıklı makalesinde, General Thomson'un üçüncü beyannamesinde, Azerbaycan arazisi üzerinde yegâne meşru bir hükümet olduğu tarzındaki ifadelerinden yola çıkarak diyordu ki: “... General Milne

\footnotetext{
${ }^{6}$ Azerbaycan, 10 Kânunusani/ 10 Ocak 1919.

${ }^{7}$ Azerbaycan, 23 Kânunusani/23 Ocak 1919.
} 
resmi surette Azerbaycan Cumhuriyeti'ni tanıdığını bildirmiştir... Demek ki Kafkasya'daki cumhuriyetlerin sulh-i umumi kongresince kabulüne ingiltere hükümeti sa'y edecektir... "Sosyal Demokratlarla Sosyal Revolüsyoner Parti mensuplarının da parlamentoya girmek istediklerine değinen Resulzade, "Bismillah, dahil olsunlar. Hakiki sosyalist olsalar, bundan fazla reftar edemezler. Bu reftara onlar imdi değil, çoktan sulûk etmelidirler." diyordu ${ }^{8}$.

Azerbaycan'ın Paris Barış Konferansı'ndan beklentileri oldukça fazla görünmekteydi. Nitekim Azerbaycan gazetesi 1 Ocak 1919 tarihli nüshasında Geçmiş Felaketler ve Gelecek Ümitler başlığı altında şunları yazmakta idi: "Geçen 1918 Yılı Azerbaycan Türk ve İslamlarının tarihinde en rengârenk, karışık ve muğlak bir sahife işgal edecektir. Zira hemin yılda Azerbaycan Türkleri bir müddet mütemadi hayat ile memat arasında kalıp aharda hayattan na-ümit olurken birden hayat güneşi onların yüzüne güldü. Rezil ve ahlaksız düşmanların taht-ı tazyikinde paymal oldukları vakit, Azerbaycanlılar öz hem-cinsleri olan Osmanlı Türkleri tarafından büyük bir muavenet görüp, onların fedakârlığı sayesinde sahil-i necata çattılar... Türklerin muaveneti olmasa idi Azerbaycan ve onunla bütün Kafkas, Bolşevik ve Daşnak tehlikesi altında olup, buradaki Türkler tamamen mahvolup giderdiler. Erivan, Bakü ve Şamahı hadisatı bize bunu aydınca gösterdi... Türklerin muaveneti Azerbaycan islamlarını ve onların istiklaliyetini maddiyen muvakkat olarak temin ettiyse, müttefiklerin böyle muavenet ve hüsnü rağbetleri Azerbaycan istiklaliyetinin manevi cihetini temin edip daimi surette payidar olması için bize ümit veriyor. Işste geçen 1918. Yılda istiklalimiz kendimiz tarafından ilan edildiyse, ümitvarız ki yeni 1919. yılda istiklalimiz özgeler tarafından dahi itiraf ve tasdik olunur."

Bölgede huzuru bozan Ermeniler, bir yandan Gürcülerle savaşırken diğer yandan Türklere karşı şiddet gösterisinde bulunuyorlardı. Cebrail kazasında 30 kadar silahlı Ermeni, halkın canına ve malına kastetmişler, Nuraşen kenti yakınlarında ise altı silahlı Ermeni halkın mallarını yağmalamışlardır. "Erivan ve Karabağ Müslümanlarının feryatları yakinen ki bütün Müslümanların kalbini od gibi yandıracak... Evet Erivan Müslümanlarının esef-engiz hali bize çoktan malumdur.

\footnotetext{
${ }^{8}$ Azerbaycan, 28 Kânunusani/28 Ocak 1919.

${ }^{9}$ Azerbaycan, 1 Kânunusani /1 Ocak 1919.
}

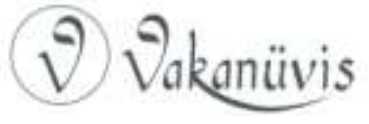


Daşnaksutyun adlı Ermeni Kulturlar Fırkasının kahramanı Dro'lar iki yüz adet İlam köylerini top ve tüfengiyle hak ile yeksan ettiği hepimizin malumudur... Erivan Müslümanlarının bilumum mahvolup gideceğine şüphe olabilmezdi. Yalnız Osmanlıların vürudu onların hayatını kurtardı. Indi ise müttefiklerin vürudundan sonra Osmanlı kıtaları Kafkasya'yı boşalttı. Ve müttefikler öz beyannamelerinde söylemişler ki Kafkas'ın muhafaza meselesini bundan sonra onlar öz uhdelerine götürüyorlar. Lakin Türkleri Kafkasya'yı boşaltmaya mecbur eden müttefikler orada yaşayan milletlerin muhafazasını temin etmek meselesinde bir kadar yanlışlıklara uğradılar... Heyhat onlar bunu bilmediler ki Ermenistan denilen mahal insan ve islam kanını yerikleyen yırtıcılar eline geçmiştir ki karşılarında kuvve gördüklerinde tilki gibi nevaziş gösteriyorlar, fakat bir kadar özlerini güçlü hissettikte bi-neva islam ahalisinin kanını su yerine içiyorlar." "Antranik'in eşkıya desteleri karşılarına düşen Müslüman kendlerini mukavemetsiz olursa üzelce yağma ve garet ediyorlar. Sonra ise halkını kılıç ve gülleden geçiriyorlar... O etraf dağıtırken ona bu barede ingilizlerden emir verildiğini bildiriyor. Zengezor ve Erivan mahallinde olan müslümanların bu tezlik ile imdadına giden olmazsa bu vahşi Ermeniler oradaki müslümanları yok etmekten çekinmeyecekler." ${ }^{\text {"10 }}$ Azerbaycan Hükümeti 5 Ocak 1919 Ermeni Hükümeti'ne verdiği notada, silahlı Ermenilerin Erivan'daki Türklere karşı yağma ve kıtalde bulundukları, canını kurtarmak için kaçan Müslümanlardan 300'den fazlasının Aras çayında boğuldukları, bundan başka Ermeni kentlerinde nizamiye askerlerinin konuşlandırıldığı bildiriliyor, kötü duruma son verilmesi isteniyordu $^{11}$.

26 ve 28 Mayıs günleri Tiflis'te teşekkül ettirilen Güney Kafkas cumhuriyetleri Osmanlı diplomasisinin bir başarısı şeklinde görülebildiği kadar, Azerbaycan adına yüzyıllık esaretin sonu olarak kabul ediliyordu. 15 Eylül 1918'de Kafkas İslam Ordusu'nun Dunstervill Force'a rağmen Bakü'yü zapt etmesi bu inancı pekiştirmekle kalmadı aynı zamanda Kuzey Kafkasya'ya doğru yeni bir hamle üstünlüğü elde etti. Mondros Mütarekesi imzalandığı tarihte Osmanlı ve Azeri kuvvetleri Petrovsk'ta bulunuyorlardı. Mütareke'nin 11. Maddesi bu

\footnotetext{
${ }^{10}$ Azerbaycan, 6 Kânunusani/6 Ocak 1919.

${ }^{11}$ Azerbaycan, 7 Kânunusani /7 Ocak 1919
}

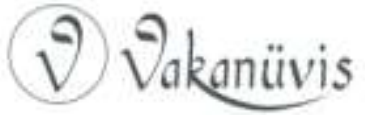


hamlenin karşılığı idi, üstelik birleşik donanmanın Boğaziçi'nde demirlediği bir sırada Bakü ile İstanbul arasında kardeşlik, soydaşlık, dindaşlık kavramlarından söz ediliyordu. Halk gazetesi muhabirlerinden biri 6 Aralık 1918'de Azerbaycan Hükümeti'nin istanbul'daki olağanüstü temsilcisi Ali Merdan Topçubaşıef ile gerçekleştirdiği mülakatın -ki aynı mülakat kısaltılarak bir gün sonra Hadisat'ta yayınlanmıştır- giriş bölümünde yazıyordu ki: "Şurada burada bir islam hükümeti teşekkül ettiğini duymak kadar bizim için badi-i sürur bir şey tasavvur olunur muydu? Türk kardeşlerimizin hürriyet içinde ve müstakilen yaşadıklarını duymak ne büyük bir iftihardı? Ancak Rusya'nın muhtelif yerlerinde müteşekkil olup henüz itilafiyyûnca tasdik edilmeyen hükümetler hakkında sulh masasında şu günlerde ne gibi mukarrerat ittihaz edileceği mûcib-i meraktır. Acaba bu hükümetlerin suret-i teşekkülü nazar-ı itibara alınacak mı? Yoksa bunların tekrar büyük Rusya'ya raptı hususu mu müzakere edilecek." Bu uzun mülakatında Azerbaycan sefirinin dikkat çeken sözleri arasında umut verici olanlar bulunduğu gibi tereddüt ifade edenler de vardı. Ermenistan, Gürcistan ve Azerbaycan Hükümetlerinin sulh konferansına katılmak için hazırlandıkları, kurullarını oluşturdukları halde, ABD Başkanı Wilson'un Büyük Rusya adına bir heyeti kongreye kabul ederek kendilerini davet etmeyeceğine dair kuşkularını dile getirdikten sonra, "Sulh masasında bir yerimiz olmalıdır. Bu lazımdır. Israrlarımız neticesinde hüsnü kabul göreceğiz ... Bu muhterem zevat bizim yeniden bir Rus Çarlığı idaresi altına girmemizin mehalikini ve imkânsızığını er geç takdir edeceklerdir." diyordu. Azerbaycanlıların Osmanlı Türkleri hakkında neler düşündüklerini soran muhabire verdiği cevapta ise şunları söylüyordu: "Türkler için hudutsuz bir muhabbet vardır. Ve Türkiye ile Azerbaycan her biriyle iyi danışmalıdır. Bütün islam akvamı birlik olmalıyız. El ele çalışmalıyız. Ben burada sadrazamınızla ve nazırlarınızla görüştüm. Hepsi hakkımızda iyi fikirler besliyorlar." Mülakatın sonunda Yazı İşleri Müdürü Vedat Bey görüşmelere katılmış, Ali Merdan Bey, Rusların kötü muamelelerinden, hapislerde nasıl yattığından bahsetmiştir ${ }^{12}$.

Öte yandan Tiflis'teki görüşmelerden sonra Azerbaycan ve Gürcistan heyetleri 11 Ocak 1919'da Batum'a geldiler. Her iki heyet

${ }^{12}$ Haber, 6 Kânunuevvel 334/6Aralık1918, Hadisat, 7Kânunuevvel 334/7 Aralık 1918.

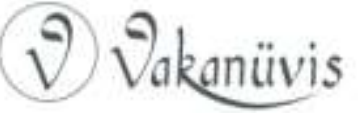


burada bazı mühim meseleler hakkında meclisler aktederek fikir alışverişinde bulundular. "Ahiren Batum'a azimet eden Azerbaycan Heyet-i Murahhasası, Batum mahalli islamları tarafindan mutantan bir surette istikbal edilerek Doktor Mahmut Beyefendief cenapları hanelerinde şereflerine ziyafet verilmiştir. Ziyafete Acara ümera ve vekilleri iştirak etmişlerdir. Bade Acara vekilleri ile birlikte heyet-i murahhasa hususi bir meclis aktederek müdavele-i efkâr etmişlerdir." Bilahire 16 Ocak'ta bir İngiliz gemisiyle İstanbul'a doğru yola çıktılar ${ }^{13}$.

Yeni Gün gazetesinin 23 Ocak 1919 tarihli haberine göre, Azerbaycan Murahhas Heyeti 21 Ocak'ta İstanbul'a gelmiştir. Ali Merdan Topçubaşıyef'in başkanlığındaki hu heyet uluslararası toplantılara katılmak, siyasi, iktisadi, mali konularda taahhütnameler imzalamak gibi geniş yetkilere sahip bulunuyordu. Ali Merdan Beyle mülakat gerçekleştiren Yeni Gün muhabiri, başkanın Azerbaycan'ın en eski ve asil Türk ailesine mensup olduğunu, meclis başkanlığının yanı sıra Türkiye fevkalade elçisi bulunduğunu yazıyordu. Aynı gazetenin 10 Mart 1919 tarihli bir başka haberinde, yaklaşık bir aydan beri İstanbul'da bulunan Azerbaycan heyetinin Paris'e gitmeleri hususunun evvelki gün (8 Mart) İngiliz ve Fransız mümessilleri tarafından kendilerine bildirildiğine dair duyumlar alındığını yazıyordu. Azerbaycan'ın Paris Barış Konferansı'na katılma gündemine mümasil, Osmanlı hükümetleri de çaba sarf ediyorlar, bir yandan da işgaller ve idareye müdahalelerle uğraşmak zorunda bulunuyorlardı. Dolayısıyla sansürlü i̇stanbul basını bu konulara daha fazla yer vermek zorunda kalıyor, Azerbaycan gündemini ikinci sırada tutuyordu. Azerbaycan Heyet-i Murahhasası, başlarında Ali Merdan Topçubaşıef bulunduğu halde Paris'e müteveccihen 22 Nisan 1919'da İstanbul'dan ayrıldı ${ }^{14}$. Bu konu ile ilgili olarak Hadisat'ta "Bir müddetten beri şehrimizde bulunan

${ }^{13}$ Azerbaycan, 31Kânunusani 335/31 Ocak 1919. Batum'dan ayrılışa dair gazetenin verdiği bilgiler birbirini tutmamaktadır. Bir yerde Azerbaycan ve Gürcistan heyetlerinin 11 Ocak'ta Batum'a geldiklerini ve 16 Ocakta buradan ayrıldıklarını yazarken bir başka yerde Azerbaycan Heyet-i Murahhasasının Ocak ayının 18 inde İstanbul'a müteveccihen yola çıktığını haber vermektedir. Bu da heyetlerin ayrı ayrı yola çıkmış oldukları gibi bir yanılgıyı da beraberinde getirmektedir.

${ }^{14}$ Zaman, 24 Nisan 335/1919.

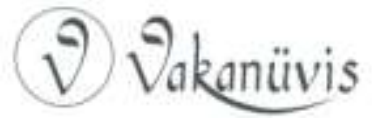


Azerbaycan Heyet-i Murahhasası dün Paris'e müteveccihen şehrimizden mufarakat eylemiştir." ${ }^{15}$ deniliyordu.

Azerbaycan heyeti, üç ay kadar i̇stanbul'da kaldı veya çeşitli bahanelerle bekletildi. Söz konusu zaman zarfında Türkiye, itilaf devletlerinden kaynaklanan büyük sıkıntılarla karşı karşıya bulunuyordu. Azerbaycan basını, kendi problemleriyle ilgilenmekle beraber Türkiye'nin durumunu da yakından takip ediyordu. Aynı günlerde Azerbaycan'ın başkentinde ve ülke genelinde 31 Mart-2 Nisan 1918'de Bakü'de Ermeni-Bolşevik ikilisinin gerçekleştirdiği katliam ve mezalimin ${ }^{16}$ birinci yıldönümü münasebetiyle şühedayı anma törenleri düzenlendi. Şehrin en korkunç ve en çok kıtale uğramış yerlerinden Mehmedli Mahallesi ve Hacı Ağababa Tekkesinde halk tarafından şehit düşenlerin ruhlarına ithafen dualar okunmak üzere taziye meclisleri kurulmuş, mezar ziyaretleri düzenlenmiştir. Bunun yanında i̇stiklal Bayramı kutlama hazırlıkları erkendan başlatıldı. Azerbaycan gazetesi 27 Mayıs 1919 tarihli nüshasında, “...Mayın 28 inde Azerbaycan istiklaliyetinin birinci sene-i devriyesi olmak münasebetiyle umum ahaliye heman günün tantanalı surette olarak bayram edilip ve umum hükümet ve cemaat müesseseleri ve mektebin kapanması hakkında ittilaat versinler." Diyordu. 30 Mayıs 1919 tarihli diğer bir nüshasında kutlamaların nasıl gerçekleştirildiğinden bahsediyordu. Diğer taraftan 1919 Haziranında Osmanlı Hükümeti'nin konferansa Sadrazam Damat Ferit Paşa başkanlığında bir heyetle katılması ve barış projesini seslendirmesi, itilaf temsilcilerini hiç memnun etmese de Azerbaycan basınında yankı uyandırmış, İstanbul gazetelerinden iktibaslar yapmak suretiyle bu olayın okuyuculara duyurulması sağlanmıştır.

\footnotetext{
${ }^{15}$ Hadisat, 24 Nisan 335/1919.

${ }^{16}$ Dursun Ali Akbulut, "Bakü'de 31 Mart (1918)Katliamının Birinci Sene-i Devriyesi”, II. Uluslararası Türk-Ermeni Münasebetleri Sempozyumu, 21-22 Haziran 2007 Erzurum, s.285-297. Ronald Grigor Suny, Bakü Komünü, Türkçesi: Kudret Emiroğlu, İstanbul 1990. Osmanlı basınında bu meşum olayla ilgili zamanında ve basında yeterince habere yer verilmediği görülmektedir. Ancak Tasviri Efkâr, 23 Mayıs 1918 tarihli nüshasında Milli Ajans kanalıyla Cenevre'den aldığı haberde, “Ajans Havas'ın Bakü'den istihbar ettiğine göre Müslümanlarla Sovyet taraftarları arasında mücadele şiddet kesp etmiştir." denilmekte, 3.000 i mütecaviz maktul, bir o kadar da mecruhun bulunduğu, şehrin ateşler içinde kaldığı bildirilmekte idi. Türk basınında daha çok Bakü'nün kurtuluşu ile ilgili haberlere yer verilmekte idi.
}

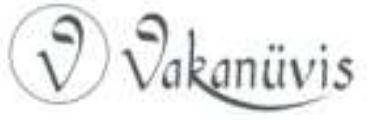


Azerbaycan heyetinin İstanbul'dan ayrılmasından bir süre sonra, 1919 yılı sonları ile 1920 yılı başlarında Paris'ten sevindirici haberler gelmeye başladı. İstanbul basını tekrar Azerbaycan konusuna odaklanmış, bağımsızığının uluslararası düzeyde tanındığına dair haber ve makalelere yer vermeye başlamıştır. Tasvir-i Efkâr, 19 Ocak 1920 tarihli nüshasında Azeri ve Gürcü Hükümetlerinin Resmen Tasdiki başlığı altında her iki hükümetin de bağımsızlıklarının Milletler Cemiyeti'nde bulunan İtilaf Devletleri mümessilleri tarafından tasdik edildiğini, neşir ve ilan olunduğunu belirttikten sonra şöyle diyordu: "Bu haber Türkiye mehafilinden pek tabii, pek ziyade memnuniyetle karşılanmıştır. Azerbaycan, din ve ırktaşlarımız tarafından teşkil edilmiş bir hükümet olduğu gibi Gürcistan da kısmen dindaşlarımızı şamil bir ülkedir. Her iki unsurun kabiliyet-i medeniyesi pek ziyade olduğu cihetle birer hükümet-i müstakile olarak cemiyet-i düveliyeye karışmaları alem-i medeniyet için de mucib-i istifade ve memnuniyettir. Mazlum olduğu vecihle gerek Azerbaycan, gerek Gürcistan hükümetleri Rusya'nın inhilalinden beri fiilen mevcuttur. Teşekküllerinden beri geçen zaman içinde her iki hükümet pek mükemmel teşkilat vücuda getirmeye muvaffak olmuşlar, Bolşevik cereyanının tevessüüne mani olmak suretiyle bir nokta-ı nazardan itilaf devletlerinin amal ve mekasıdına da hizmet eylemişlerdir." Gazete ayrıca Azerbaycan'ın İstanbul'daki temsilcisi Yusuf Bey Vezirli ile Azerbaycan bayrağının fotoğraflarına yer vermiş, "Türklük aleminin matemler içinde bulunduğu şu vahim zamanlarda bir Türk hükümetinin teşekkül etmesi ve mazhar-ı tasdik olması, bir tesliyet mahiyeti almıştır." sözleriyle meramını anlatmaya çalışmıştır. Vakit gazetesi ise bir gün sonra konu ile ilgili Ahmet Emin imzalı Azerbaycan'ın Istiklali unvanlı baş yazısında, “Azerbaycan'ın müstakil bir devlet olarak tanınması, bütün islam aleminde hayırlı bir haber-i beşaret-i diniye telakki edilecek ve derin bir memnuniyet uyandıracaktır."17 diyordu.

Yeni Gün ise 21 Ocak 1920 tarihli nüshasında, Azerbaycan Hükümeti'nin, Azerbaycan Milli Marşı ile Azerbaycan Armasının tanzimi için yarışma düzenlediğini, eseri seçilenlere nakdi mükâfat verileceğini yazıyor, Bolşeviklere karşı Azerbaycan'a yardım edilmesi gerektiğinden söz ediyordu. Çünkü Azerbaycan siyaset sahasına çıkar

${ }^{17}$ Vakit, 20 Kânunusani 336/20 Ocak 1920.

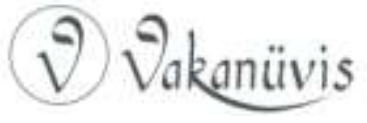


çıkmaz böyle bir sorunla karşılaşmış, Bolşeviklere karşı Kafkasları savunma vazifesi almıştı. Bu açıdan bakıldığında bağımsızlığın uluslararası siyasette tanınmış olması bir başına yeterli görünmüyor, aynı zamanda onun kuvvetle savunulması gerekiyordu. Bu konuyla ilgili olarak: "Denikin işi çok yanlış tuttu. Bir taraftan Bolşeviklerle uğraşırken diğer taraftan Azerbaycan'a karşı da tecavüzkâr bir vaziyet aldı. Filhakika Denikin son zamanlarda Azerbaycan'a karşı hiçbir maksat-ı tecavüz beslemediğini söylüyor idiyse de Şimali Kafkasyadaki İslam Cumhuriyetini mahvettikten sonra günün birinde Azerbaycan'a da taarruz edecekti. Takip ettiği gaye bunu istilzam ediyordu. Şimdi Denikin bir amil olabilecek vaziyetten çıkmıştır. Bolşevik tehlikesinin daha cenuba, şarka doğru tevessüüne mani olmak için Azerbaycan gibi, Gürcistan gibi yeni hükümetleri tutmaktan, mazhar-ı muavenet eylemekten başka çare yoktur." diye yazilıyordu. Nitekim Paris'teki Azerbaycan ve Gürcistan heyet başkanları memleketlerinin ihtiyaçları hakkında Yüksek Meclis'e ${ }^{18}$ açıklamada bulundular. Bolşevikleri durdurmaya karar verdikleri halde şimdi silah ve mühimmata ihtiyaçları bulunduğunu beyan ettiler. Meclis bu açılamayı önemsediğinden Azerbaycan ve Gürcistan ahalisine, hali hazırda Denikin ordularına yapıldığı gibi yardımda bulunmak için gereken önlemleri almaya karar verdi ${ }^{19}$. "Azerbaycan Cumhuriyet-i cedidesinin ahiren sulh konferansınca resmen tasdiki, muhiti Osmaniyede pek derin, pek samimi bir hiss-i sürur uyandırmıştır. Milletimizin Azerbaycanlılarla olan revabıt-ı örfiye, diniye ve tarihiyesi o mertebe hudutludur ki Moskof Çarlığının senelerce devam eden dessas siyaseti hemdin iki milleti hakayık-ı tarihiyeyi tahrif suretiyle olsa da ... Osmanlı Türkleriyle Azeri Türkler arasında meveddet ve muhabbed-i kadime aynı şekilde devam edip gitmiştir. Sulh konferansı Azerbaycan Cumhuriyeti cedidesini tasdik etmek şüphesiz bir eser-i kiyaset göstermiştir. Katiyen eminiz ki eğer Azerbaycan, tesvilat-ı siyasiyeden masun bırakılır ve siyasi entrikalara kurban edilmezse az vakit içinde

18 Bu meclis, 19 Ocak 1920 de Mösyö Clemenceau'nun başkanlığında toplandı. Toplantıya katılanlar, Mareşal Foch, Mareşal Wilson, Amiral Beni, Mösyö Winston Churchill, v.s. den ibaretti. Meclis Hariciye Nezaretinde toplanacak olup, Adriyatik meselesini de ele alacaktı (Vakit, 21 Kânunusani 336/21 Ocak 1920).

${ }^{19}$ Yeni Gün, 22 Kânunusani 336/22 Ocak 1920. Alemdar, 22 Kânunusani 336/22 Ocak 1920.

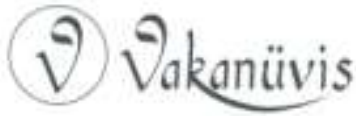


Azerbaycanlılar, hakiki bir inkişaf ve terakki devresinin imkânlarından azami faydalar temin ederler ve Türk ırkının bu derece terakkiye, imara müstenit olduğunu ispat ederler. Olur ki gölge edilmesin!.." ${ }^{20}$ Nitekim gelen haberlere nazaran, Yüksek Konsey Rus milletine karşı bir merhamet hissiyle ablukanın kaldırılmasına, Rusya ile ticaretin serbestisine karar vermiştir ${ }^{21}$. Japonya Hükümeti'nin de Azerbaycan'ın bağımsızlığını tanımak hususunda itilaf devletleriyle müşterek olduğunu Azerbaycan'ın seçilmiş heyetine bildirmiştir ${ }^{22}$.

Azerbaycan'ın bağımsızlığının uluslararası alanda tanınmış olması İstanbul'da sevinç ve heyecanla karşılandı. Darülfünun Hukuk Medresesiyle Ziraat Mektebi'nden seçilen bir heyet 20 Ocak'ta Azerbaycan'ın sefarethanesini ziyaretle bağımsızlığın uluslararası düzeyde tanınmış olmasından duyulan memnuniyeti, mümessil Yusuf Bey Vezirli'ye bildirilmiş, Darülfunun adına kutlamada bulunulmuştur. Darülfünun Edebiyat Medresesi de söz konusu bağımsızlıktan dolayı bir bildiri neşretmiş, bazı bölümlerine gazetelerde yer verilmiştir ${ }^{23}$. Yine bu günlerde Bakü zenginlerinden biri şehrin kurtarılması sırasında şehit düşen kahramanların hatırasına hürmeten bir abide yaptırmış, Bolşevikler tarafından tahrip edilen caminin onarımı için yarım milyon ruble bağışta bulunmuştur. Bir kutlama mesajı da Mehmet Ziya Bey'den geldi. Nişantaşı'nda Azerbaycan Hükümeti Temsilcisi Yusuf Bey Vezirli'ye hitaben çekilen telgrafta deniliyordu ki: “Asya'nın necip ve vakur kitle-i islamiyesi meyanında necabet-i ırkiye ve salabet-i ahlakiyesiyle mümtaz ve kabiliyeti temeddiniyesi muvakkar olan

\footnotetext{
${ }^{20}$ Tasviri Efkâr, 25 Kânunusani 336/25 Ocak 1919.

${ }^{21}$ ileri, 22 Kânunusani 336/22 Ocak 1920.

${ }^{22}$ Akşam, 12 Şubat 336/1920. "Heyet Fransa'ya giriş izinleri için üç ay istanbul'da bekleyerek yolda gecikmişti. Diğer bir küçümseyici tavır, Thomson'dan tavsiye mektupları taşıyan Ağayef'in Ingilizler tarafından tutuklanıp ... Malta'ya sürülmesiydi. Azerbaycanlılar Paris'e ancak 1919 Nisanında varabildiler. Lobi oluşturmakta geç kalmışlardı. Üstelik Paris'te Ermeni yanlısı hareket veya gürcü Menşeviklerin uluslararası sosyalizm bağları bulunduğu halde Azerbaycan bu desteklerden yoksundu. itilafçılarla görüşmeler yaptıysalar da pek başarılı sayılmazlardı. Wilson'un sözleri umutlandırıcı değildi. Ona göre konferans dünyayı küçük parçalara ayırmayı amaçlamıyordu. Dolayısıyla Rusya'nın durumu belli olmadan Azerbaycan sorunu çözülemezdi." (Tadeusz Swietochowski, Müslüman Cemaatten Ulusal Kimliğe Rus Azerbaycanı 1905-1920, Türkçesi: Nuray Mert, İstanbul 1988.)

${ }^{23}$ Yeni Gün, 21 Kânunusani 336/21 Ocak 1920.
}

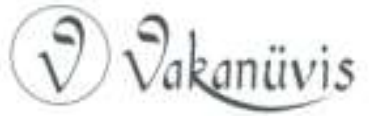


Azerbaycan Türk Hükümetinin hadise-i istiklalini müslüman ve Türk alemi için pek mesut ve şerefli bir hadise olmak üzere telakki eden ihtifal-i milli heyeti ... samimi tebrikâtını heyet-i idare kararıyla zat-ı necibanelerine arz eyleriz." ${ }^{24}$ Cemiyet-i Sufiye ile Türk Ocağı ayrı ayrı heyetler oluşturarak Azerbaycan sefaretine gönderdiler ve bağımsızıklarını tebrik ettiler. Galatasaray Mektebi'nden seçilen bir heyet de 23 Ocak'ta sefarethaneye giderek mümessil Yusuf Bey Vezirli'yi kutladılar ${ }^{25}$. Osmanlı hanımları da tebriklere iştirak ettiler. Inas Sanayi-i Nefise Mektebi adına dört öğrenci Azerbaycan Sefarethanesi'ne giderek mümessil Yusuf Bey Vezirli tarafından kabul edilmişler ve kardeş Azerbaycan Hükümeti'nin bağımsızlığını tebrik etmişlerdir. Mümessil Bey kadınlar adına ilk defa kutlamada bulunulduğundan dolayı memnuniyet duyduğunu, kendisinin de ressamlıkla uğraştığını, sanatı pek sevdiğini söylemiştir ${ }^{26}$. Türk Ocağı tarafından 30 Ocak Cuma günü saat ikide Darülfunun konferans salonunda bir toplantı düzenlendi. Halide Edip hanımın başkanlığındaki toplantıda en ön sıralarda Çürüksulu Ahmet ve îhsan Paşalarla Mehmet Emin ve Ruşen Eşref Beyler gibi önemli şahsiyetler yer aldılar. Halide Edip'le birlikte Yusuf Akçora, Ruşen Eşref, Hamdullah Suphi Beyler de konu hakkında konuşmalar yaptılar ${ }^{27}$.

Kutlamalara çok önemli bir destek de son Osmanlı Mebusan Meclisi'nden geldi. Bolu Mebusu Tunalı Hilmi Bey 22 Ocak 1920 tarihli birleşimde bağımsızlığı onaylanan Azerbaycan Hükümeti'ne tebrik telgrafı çekilmesini istedi. Bazı mebusların gündemde böyle bir konunun bulunmadığını söylemelerine karşı Tunalı Hilmi Bey sözlerini şu şekilde sürdürdü "... Azerbaycan istiklali tanındı. Bir çoklarımız istanbulumuzun, istiklalimizin elden gideceğinden korkuyorlar. Daima tekrar ettiğim bir sözüm vardır: $O$ da Türk ölse de ölmez... İstiklalim doğar batar, Şarktan garptan güneş gibi, Azerbaycan kalpte yatar, Bin müjdeli bir eş gibi." Gündeme geçilmesi taleplerine karşı Hamdullah Suphi Bey de bir konuşma yaparak Tunalı Hilmi Bey'in teklifine

\footnotetext{
${ }^{24}$ Yeni Gün, 22 Kânunusani 336/220cak 1920.

${ }^{25}$ Yeni Gün, 23 Kânunusani 336/23 Ocak 1920. Tasviri Efkâr, 24 Kânunusani 336/24

Ocak 1920.

${ }^{26}$ Alemdar, 27 Kânunusani 336/27 Ocak 1920.

${ }^{27}$ Yeni Gün, 29 ve 31 Kânunusani 336/29 ve 31 Ocak 1920, Vakit 31 Kânunusani 336/31 Ocak 1920.
}

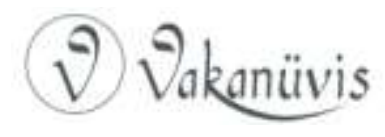


katıldığını, bir kardeş hükümetin doğduğunu belirttikten sonra, meclisin en derin ve samimi dileklerini bildirecek bir telgrafın çekilmesini, Gürcü Hükümeti'ne de aynı dileklerin arz edilmesini önerdi. Alkışlar ve muvafık sesleri ile normal gündeme geçildi ${ }^{28}$.

Paris Barış Konferansı gibi dünya meselelerinin konuşulduğu, mağlup devletlerin ve milletlerin kaderlerinin belirlendiği ortamda Kafkas berisinde üç cumhuriyetin bağımsızıkları uluslararası alanda tanınmış ve teminat altına alınmış olmasına rağmen, verilen sözlerin, güvencelerin ne kadar dayanaksız ve geçersiz olduğu ortaya çıkmıştır. Osmanlı başkentinin işgal altına alındığı, San Remo Konferansı'nın yapıldığı, Büyük Millet Meclisi'nin açıldığı dönemde, 27 Nisan'da Bakü'nün Bolşevikler tarafından işgali tam anlamıyla felaket olmuş, acılı yıllar uzayıp gitmiştir. Netice itibariyle, bir defa yükselen bayrak bir daha inmedi. 18 Ekim 1991'de Sovyetler Birliği'nden ayrılarak ikinci kez bağımsızlığını kazanan, başka bir deyişle ikinci cumhuriyetini ilan eden Azerbaycan'ın, üç renkli bayrağıyla mesut yaşamasını diliyoruz.

\section{Kaynakça}

Akbulut, Dursun Ali, “Bakü'de 31 Mart (1918)Katliamının Birinci Sene-i Devriyesi", II. Uluslararası Türk-Ermeni Münasebetleri Sempozyumu, 21-22 Haziran 2007 Erzurum, s.285-297.

Akşam, 12 Şubat 336/1920.

Alemdar, 22 Kânunusani 336/22 Ocak 1920.

Alemdar, 27 Kânunusani 336/27 Ocak 1920.

Azerbaycan Cumhuriyetinin Ansiklopedisi, c. II, Bakü 2005.

Azerbaycan Halk Cumhuriyet Ansiklopedisi, c. I, Bakı 2005.

Azerbaycan, 1 Kânunusani /1 Ocak 1919.

Azerbaycan, 10 Kânunusani/ 10 Ocak 1919.

Azerbaycan, 11 Nisan 1919.

Azerbaycan, 23 Kânunusani/23 Ocak 1919.

Azerbaycan, 28 Kânunusani/28 Ocak 1919.

Azerbaycan, 3 Kânunusani/ 3 Ocak 1919.

Azerbaycan, 30 Mayıs 1918.

Azerbaycan, 31Kânunusani 335/31 Ocak 1919.

${ }^{28}$ Meclisi Mebusan Zabıt Ceridesi, Dönem IV, Devre I, c. I, s. 13.

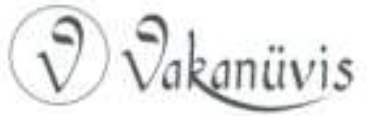


Azerbaycan, 6 Kânunusani/6 Ocak 1919.

Azerbaycan, 7 Kânunusani /7 Ocak 1919

Haber, 6 Kânunuevvel 334/6Aralık1918.

Hadisat, 24 Nisan 335/1919.

Hadisat, 7Kânunuevvel 334/7 Aralık 1918.

İleri, 22 Kânunusani 336/22 Ocak 1920.

Meclisi Mebusan Zabıt Ceridesi, Dönem IV, Devre I, c. I. Tasviri Efkâr, 23 Mayıs 1918.

Tasviri Efkâr, 24 Kânunusani 336/24 Ocak 1920. Tasviri Efkâr, 25 Kânunusani 336/25 Ocak 1919.

Vakit 31 Kânunusani 336/31 Ocak 1920.

Vakit, 20 Kânunusani 336/20 Ocak 1920.

Vakit, 21 Kânunusani 336/21 Ocak 1920.

Yeni Gün, 21 Kânunusani 336/21 Ocak 1920.

Yeni Gün, 22 Kânunusani 336/22 Ocak 1920.

Yeni Gün, 22 Kânunusani 336/220cak 1920.

Yeni Gün, 23 Kânunusani 1335/23 Ocak 1919.

Yeni Gün, 23 Kânunusani 336/23 Ocak 1920.

Yeni Gün, 29 ve 31 Kânunusani 336/29 ve 31 Ocak 1920.

Zaman, 24 Nisan 335/1919. 